\title{
PERMAINAN WHAT'S IN HERE? SEBAGAI ALTERNATIF METODE PEMBELAJARAN UNTUK MELATIHKAN KETERAMPILAN BERTANYA SISWA SEKOLAH DASAR
}

\author{
Selly Nurina Suraya*
}

\begin{abstract}
Education is a systematic process to improve human dignity in a holistic manner that allows self potentials (affective, cognitive, and psychomotor) develop optimally. Curriculum 2013 adheres to the basic view that knowledge cannot be moved away from the teacher to the learner. For learners, learning should be shifted from "notified" to "actively seek out". One of methods that can be applied is a game "What's in here?", that is learning with the game questions that make students happy to learn but it is also able to educate students to be more creative thinking and develop knowledge. The game "What's In Here?" can be used as an alternative method of teach for training elementary school students to have questioning skills.
\end{abstract}

Keywords: questioning skills, game "What's in Here?” elementary school students

\begin{abstract}
Abstrak
Pendidikan merupakan proses sistematik untuk meningkatkan martabat manusia secara holistik yang memungkinkan potensi diri (afektif, kognitif, psikomotor) berkembang secara optimal. Kurikulum 2013 menganut pandangan dasar bahwa pengetahuan tidak dapat dipindahkan begitu saja dari guru ke peserta didik. Bagi peserta didik, pembelajaran harus bergeser dari "diberi tahu" menjadi "aktif mencari tahu". Salah satu metode yang dapat diterapkan adalah permainan What's in here?, yaitu pembelajaran dengan permainan pertanyaan yang menjadikan siswa senang dalam belajar selain itu juga mampu mendidik siswa untuk lebih kreatif berpikir dan mengembangkan pengetahuannya. Permainan What's In Here? dapat digunakan sebagai alternatif metode pembelajaran untuk melatihkan keterampilan bertanya pada siswa sekolah dasar.
\end{abstract}

Kata Kunci : Keterampilan bertanya, Permainan What's In Here?, Siswa SD

\section{A. Pendahuluan}

Berdasarkan Undang - Undang RI No. 20 Tahun 2003 Tentang sistem Pendidikan Nasional, pendidikan adalah usaha sadar dan terencana untuk mewujudkan suasana belajar dan proses pembelajaran agar peserta didik secara aktif mengembangkan potensi dirinya untuk memiliki kekuatan spiritual keagamaan, pengendalian diri, kepribadian, kecerdasan, akhlak mulia, serta keterampilan yang diperlukan dirinya dan masyarakat. Sehingga pendidikan sangat diperlukan untuk setiap orang. Di dalam pendidikan pasti ada proses pembelajaran.

* Selly Nurina Suraya adalah Dosen Prodi PGSD UNUSA Surabaya 
Pembelajaran merupakan suatu proses yang kompleks dan melibatkan berbagai aspek yang saling berkaitan. Oleh karena itu untuk menciptakan pembelajaran yang kreatif dan menyenangkan diperlukan berbagai keterampilan guru dalam mengajar. Turney (1973) mengungkapkan ada 8 keterampilan mengajar yang sangat berperan dan menentukan kualitas pembelajaran yaitu, keterampilan bertanya, memberi penguatan, mengadakan variasi, menjelaskan, dan membuka dan menutup pembelajaran, membimbing diskusi, mengelola kelas dan mengajar kelompok kecil dan perorangan.

Pendidikan merupakan proses sistematik untuk meningkatkan martabat manusia secara holistik yang memungkinkan potensi diri (afektif, kognitif, psikomotor) berkembang secara optimal. Sejalan dengan itu, kurikulum disusun dengan memperhatikan potensi, tingkat perkembangan, minat, kecerdasan intelektual, emosional, sosial, spritual, dan kinestetik peserta didik. Kegiatan pembelajaran merupakan proses pendidikan yang memberikan kesempatan kepada peserta didik untuk mengembangkan potensi mereka menjadi kemampuan yang semakin lama semakin meningkat dalam sikap, pengetahuan, dan keterampilan yang diperlukan dirinya untuk hidup dan untuk bermasyarakat, berbangsa, serta berkontribusi pada kesejahteraan hidup umat manusia. Oleh karena itu, kegiatan pembelajaran diarahkan untuk memberdayakan semua potensi peserta didik menjadi kompetensi yang diharapkan.

Lebih lanjut, strategi pembelajaran harus diarahkan untuk memfasilitasi pencapaian kompetensi yang telah dirancang dalam dokumen kurikulum agar setiap individu mampu menjadi pebelajar mandiri sepanjang hayat, dan yang pada gilirannya mereka menjadi komponen penting untuk mewujudkan masyarakat belajar. Kualitas lain yang dikembangkan kurikulum dan harus terealisasikan dalam proses pembelajaran antara lain kreativitas, kemandirian, kerja sama, solidaritas, kepemimpinan, empati, toleransi dan kecakapan hidup peserta didik guna membentuk watak serta meningkatkan peradaban dan martabat bangsa.

Untuk mencapai kualitas yang telah dirancang dalam dokumen kurikulum, kegiatan pembelajaran perlu menggunakan prinsip yang: (1) berpusat pada peserta didik, (2) mengembangkan kreativitas peserta didik, (3) menciptakan kondisi menyenangkan dan menantang, (4) bermuatan nilai, etika, estetika, logika, dan kinestetika, dan (5) menyediakan pengalaman belajar yang beragam melalui penerapan berbagai strategi dan metode pembelajaran yang menyenangkan, kontekstual, efektif, efisien, dan bermakna.

Di dalam pembelajaran, peserta didik didorong untuk menemukan sendiri dan mentransformasikan informasi kompleks, mengecek informasi baru dengan yang sudah ada dalam ingatannya, dan melakukan pengembangan menjadi informasi atau kemampuan yang sesuai dengan lingkungan dan jaman tempat dan waktu peserta didik hidup. Kurikulum 2013 menganut pandangan dasar bahwa pengetahuan tidak dapat dipindahkan begitu saja dari guru ke peserta didik. Peserta didik adalah subjek yang memiliki kemampuan untuk secara aktif mencari, mengolah, mengkonstruksi, dan menggunakan pengetahuan. Untuk itu pembelajaran harus berkenaan dengan kesempatan yang diberikan kepada peserta didik untuk mengkonstruksi pengetahuan dalam proses kognitifnya. Agar benarbenar memahami dan dapat menerapkan pengetahuan, peserta didik perlu didorong untuk bekerja memecahkan masalah, menemukan segala sesuatu untuk dirinya, dan berupaya keras mewujudkan ide-idenya. Guru memberikan 
kemudahan untuk proses ini, dengan mengembangkan suasana belajar yang memberi kesempatan peserta didik untuk menemukan, menerapkan ide-ide mereka sendiri, menjadi sadar dan secara sadar menggunakan strategi mereka sendiri untuk belajar. Guru mengembangkan kesempatan belajar kepada peserta didik untuk meniti anak tangga yang membawa peserta didik ke pemahaman yang lebih tinggi, yang semula dilakukan dengan bantuan guru tetapi semakin lama semakin mandiri. Bagi peserta didik, pembelajaran harus bergeser dari "diberi tahu" menjadi "aktif mencari tahu".

Di dalam pembelajaran, peserta didik difasilitasi untuk terlibat secara aktif mengembangkan potensi dirinya menjadi kompetensi. Guru menyediakan pengalaman belajar bagi peserta didik untuk melakukan berbagai kegiatan yang memungkinkan mereka mengembangkan potensi yang dimiliki mereka menjadi kompetensi yang ditetapkan dalam dokumen kurikulum atau lebih. Pengalaman belajar tersebut semakin lama semakin meningkat menjadi kebiasaan belajar mandiri dan ajeg sebagai salah satu dasar untuk belajar sepanjang hayat.

Dalam suatu kegiatan belajar dapat terjadi pengembangan sikap, pengetahuan, dan keterampilan dalam kombinasi dan penekanan yang bervariasi. Setiap kegiatan belajar memiliki kombinasi dan penekanan yang berbeda dari kegiatan belajar lain tergantung dari sifat muatan yang dipelajari. Meskipun demikian, pengetahuan selalu menjadi unsur penggerak untuk pengembangan kemampuan lain.

Dalam kegiatan mengamati, guru membuka kesempatan secara luas kepada peserta didik untuk bertanya mengenai apa yang sudah dilihat, disimak, dibaca atau dilihat. Guru perlu membimbing peserta didik untuk dapat mengajukan pertanyaan - pertanyaan tentang hasil pengamatan objek yang konkrit sampai abstrak berkenaan dengan fakta, konsep, prosedur, atau pun hal lain yang lebih abstrak. Pertanyaan yang bersifat faktual sampai kepada pertanyaan yang bersifat hipotetik.

Dari situasi di mana peserta didik dilatih menggunakan pertanyaan dari guru, masih memerlukan bantuan guru untuk mengajukan pertanyaan sampai ke tingkat di mana peserta didik mampu mengajukan pertanyaan secara mandiri.

Dari kegiatan kedua dihasilkan sejumlah pertanyaan. Melalui kegiatan bertanya dikembangkan rasa ingin tahu peserta didik. Semakin terlatih dalam bertanya maka rasa ingin tahu semakin dapat dikembangkan. Pertanyaan tersebut menjadi dasar untuk mencari informasi yang lebih lanjut dan beragam dari sumber yang ditentukan guru sampai yang ditentukan peserta didik, dari sumber yang tunggal sampai sumber yang beragam.

Namun pada kenyataannya ada hal yang kurang diperhatikan oleh guru ketika mengajar. Guru lebih senang mengambil jalan yang mudah untuk mengajar seperti ceramah, pemberian tugas, ulangan harian, evaluasi dan pembagian raport. Rutinitas seperti ini tentu saja akan menimbulkan rasa jenuh pada siswa. Untuk itu perlu adanya kekreatifan dari guru agar menjadikan proses pembelajaran menjadi menarik dan juga tetap mendidik.

Salah satu metode yang dapat diterapkan adalah permainan What's in here?. yaitu pembelajaran dengan permainan pertanyaan yang menjadikan siswa senang dalam belajar selain itu juga mampu mendidik siswa untuk lebih kreatif berpikir dan mengembangkan pengetahuannya. 


\section{B. Pembahasan}

\section{Keterampilan Bertanya}

Dalam buku Alan Peacock (2000) diceritakan bahwa pada masa dahulu kala manusia ingin terbang. Sebelum ada pesawat, manusia selalu ingin mencoba berbagai macam cara agar bisa terbang. Dari rasa ingin mencoba tersebut, manusia membuat pertanyaan untuk menjawab rasa ingin tahunya : "Bagaimana manusia bisa terbang?". Pertanyaan tersebut dijawab oleh Wright bersaudara dengan membuat pesawat terbang pertama kali. Rancangan pembuatan pesawat tersebut tidak tercantum dalam buku manapun. Wright bersaudara berusaha mencoba terus sampai terwujud pesawat untuk menerbangkan manusia. Usaha yang dilakukan Wright bersaudara ini disebut kerja ilmiah. Jadi kerja ilmiah adalah kegiatan yang bertujuan untuk menemukan jawaban melalui prosedur ilmiah dari pertanyaan yang diajukan.

Anatole France (Safa'at, Asep : 2012) menyatakan "The whole art of teaching is only the art of awakening the natural curiosity of young minds for the purpose of satisfying it afterwards". Mengajar itu seni untuk merangsang keingintahuan murid. Rasa ingin tahu itulah sesungguhnya yang akan membuat murid selalu ditantang untuk berpikir. Semua harus penuh tanda tanya, karena dengan itulah kita akan selalu berpikir.

Peranan pertanyaan merupakan bagian penting dalam menyusun sebuah pengalaman belajar bagi murid. Semua ilmu pengetahuan akan diketahui atau tidak diketahui oleh murid, hanya jika guru dapat mendemonstrasikan keterampilan bertanya yang baik dalam pembelajaran di kelas.

Dalam proses pembelajaran tujuan pertanyaan guru adalah agar siswa belajar memperoleh pengetahuan dan meningkatkan kemampuan berpikir, baik berupa kalimat tanya atau suruhan yang menuntut respon siswa.

\section{Karakteristik Siswa Usia Sekolah Dasar}

Usia siswa sekolah dasar berkisar antara 6-12 tahun. Anak usia sekolah dasar merupakan anak yang mengalami perubahan yang sangat drastis baik mental maupun fisik. Ada beberapa karakteristik siswa usia sekolah dasar yang diketahui oleh guru agar lebih mengetahui keadaan peserta didik. Sebagai seorang guru harus dapat menerapkan metode pembelajaran yang sesuai dengan karakteristik dan kebutuhan siswa.

Menurut Piaget (Eti Nurhayati, 2011:34), perkembangan kognitif anak usia sekolah dasar berada pada tahap operasional konkret. Anak-anak usia sekolah dasar dapat membentuk konsep, melihat hubungan, dan memecahkan masalah, namun hanya sepanjang mereka melibatkan objek-objek dan situasi yang anak kenal.

Anak usia sekolah dasar kelas rendah, sudah dapat mengklasifikasikan angka-angka, meskipun masih harus lebih banyak menggunakan benda konkrit. Anak diusia ini mulai dapat menyimpan pengetahuan atau hasil pengamatan dalam daya ingatannya. Pada anak usia kelas tinggi mulai dapat berpikir hipotesis deduktif, mulai mampu mengembangkan kemampuan berdasarkan kedua alternatif, mulai mampu menginferensi atau menggeneralisasikan dari berbagai kategori.

Disamping itu, Yusuf (2011: 24-25) menambahkan bahwa masa usia sekolah dasar sering disebut sebagai masa intelektual atau masa keserasian 
bersekolah. Pada masa ini anak-anak lebih mudah dididik daripada masa sebelum dan sesudahnya. Karakteristik untuk siswa SD kelas rendah diantaranya: adanya hubungan positif antara keadaan jasmani dengan prestasi (apabila jasmaninya sehat banyak prestasi yang diraih), sikap tunduk pada peraturan-peraturan, adanya kecenderungan memuji diri sendiri, suka membandingkan dirinya dengan anak lain, apabila tidak dapat menyelesaikan suatu soal maka soal itu dianggap tidak penting, anak menghendaki nilai yang baik tanpa mengingat apakah prestasinya memang pantas diberi nilai baik atau tidak. Beberapa sifat khas pada anak-anak usia SD kelas tinggi adalah amat realistik, ingin mengetahui, ingin belajar, mulai menunjukkan minat dan bakatnya, butuh orang dewasa untuk menyelesaikan tugas dan memenuhi keinginannya. Anak-anak pada masa ini memandang nilai sebagai ukuran yang tepat mengenai prestasi sekolah. Anak-anak pada usia ini gemar membentuk kelompok sebaya untuk dapat bermain bersama. Dalam permainan ini biasanya anak tidak lagi terikat kepada peraturan permainan yang sudah ada, namun membuat peraturan sendiri.

\section{Permainan What's In Here?}

Permainan adalah salah satu metode pembelajaran yang digunakan guru untuk melaksanakan pembelajaran dengan kegiatan yang menyenangkan sehingga anak dapat terlibat dan termotivasi dalam kegiatan serta mampu mengembangkan berbagai aspek pengetahuan yang ada di dalam dirinya. Kegiatan dalam permainan memberikan kesempatan bagi anak yang memerlukan penguatan ataupun pengulangan dalam menanamkan ide-ide dan keterampilan yang dimiliki secara mudah dan menarik. Melalui permainan, kegiatan pembelajaran dirancang guru agar siswa dapat mengembangkan keterampilan observasi, melatihkan keterampilan berbahasa, mengembangkan daya ingat, menerapkan pengetahuan yang didapat, serta berlatih mengembangkan ide-ide baru.

Kegiatan permainan dalam pembelajaran dapat digunakan sebagai apersepsi atau membuka pelajaran, jembatan dari satu aktivitas ke aktivitas lainnya, memotivasi siswa dalam belajar, kegiatan yang berdiri sendiri, atau sebagai bagian dari kegiatan diskusi. Secara teknis permainan dapat dilakukan dengan pertimbangan beberapa hal, yaitu : 1) Mengalokasikan waktu di sebagian pembelajaran antara 5-15 menit, 2) Mengaitkan topik yang dipelajari saat ini dengan topik sebelumnya, 3) Menyesuaikan jenis permainan dengan usia dan kemampuan anak, 4) Gunakan permainan yang sama secara teratur (anak akan suka pada kegiatan yang dikenal), 5) Sebagian besar permainan dimaksudkan agar anak-anak menjadi kolaboratif, sehingga penting bagi anak-anak untuk bekerja dalam kelompok kecil (hingga empat anak) atau dengan teman sebayanya untuk mendukung satu sama lain, berbagi dan mengklarifikasi sebelum menjawab, 6) Banyak permainan yang dapat digunakan dalam berdiskusi untuk melatih kemampuan berbicara dan mendengarkan siswa di berbagai kegiatan diskusi, 7) Berikan kesempatan siswa untuk berfikir dan mengolah pendapat atau tanggapan sebelum siswa mengutarakan atau menulis pendapatnya. Apabila siswa dan guru sudah terbiasa dengan permainan atau kegiatan tersebut, kegiatan itu dapat digunakan untuk seluruh kelas, kelompok - kelompok kecil, berpasangan, dengan topik yang berbeda. 
Rosemary Feasey (2009) mengemukakan ada tujuh kegiatan permainan menyenangkan yang dapat digunakan guru untuk mengembangkan keterampilan belajar sains siswa usia 5-11 tahun. Kegiatan permainan tersebut adalah jumpstarting science questioning, science vocabulary, science observation, science analysis, researching science information, science communication, and science revision. Jika dilihat dari macam-macam permainan yang dikemukakan oleh Rosemary Feasey, kesemuanya termasuk keterampilan proses belajar sains, contohnya science questioning yaitu keterampilan bertanya.

Fokus kegiatan science questioning adalah mengembangkan kemampuan siswa untuk bertanya dan menjawab pertanyaan. Bertanya adalah salah satu kegiatan penting dalam pembelajaran untuk merangsang rasa ingin tahu siswa terhadap segala hal dan melatih siswa untuk berpikir. Science questioning dibagi ada enam macam, yaitu 1) Questions (membuat kartu pertanyaan), 2) What's In Here? (kotak kejutan/surprise box), 3) Predators and Prey (pemangsa dan mangsa), 4) Sink the Boat, 5) Hot Seating (kursi panas), dan 6) What's the Question?

Dalam artikel ini penulis memilih What's In Here? untuk melatihkan keterampilan bertanya siswa sekolah dasar. Kegiatan What's In Here? digunakan sebagai langkah awal melatih siswa mengajukan pertanyaan untuk menebak nama benda yang berada di dalam kotak berdasarkan ciri fisik atau yang lainnya dari benda tersebut.

Di dalam belajar IPA, guru memanfaatkan kotak atau tas untuk meletakkan benda agar tampak misterius bagi siswa. Kotak atau tas dibuat semenarik mungkin agar anak-anak senang dan tertarik untuk menggunakan atau mengutak atiknya. Berikut adalah langkah-langkah melakukan kegiatan permainan What's In Here? (Rosemary Feasey, 2009) :

1) Untuk memulai, tunjukkan anak-anak kotak kejutan atau tas dan beritahu mereka bahwa ada sesuatu yang sangat istimewa atau menarik dalam kotak misalnya, prisma, tengkorak hewan, substansi berlendir atau jarum jam mainan. Jelaskan bahwa jika mereka ingin mengetahui isi kotak tersebut, mereka harus mengajukan pertanyaan. Misalnya anda mengatakan bahwa mereka hanya bisa mengajukan sepuluh pertanyaan dan mereka harus mendengarkan pertanyaan lain dan jawaban untuk membantu mereka memecahkan misteri apa yang ada dalam kotak.

2) Gunakan kartu pertanyaan (flash card) untuk membantu siswa menyusun pertanyaan atau mengarahkan pertanyaan-pertanyaan siswa.

3) Tentukan topik untuk mempersempit pertanyaan yang diajukan siswa.

4) Kegiatan ini bisa dilakukan saat apersepsi atau saat memberikan umpan balik ke siswa.

Topik pembelajaran yang dapat diajarkan dengan permainan What's In

Here? pada mata pelajaran IPA di sekolah dasar sesuai kurikulum 2013 adalah :

1. Mendeskripsikan rangka manusia dan fungsinya

2. Mengenal bagian tumbuhan

3. Mengenal organ tubuh manusia dan hewan

4. Mengenal sifat benda magnet serta penerapannya dalam kehidupan sehari-hari

5. Dan kompetensi dasar lainnya yang sifat pengetahuannya factual 


\section{Penutup}

Permainan What's In Here? dapat digunakan sebagai alternatif metode pembelajaran untuk melatihkan keterampilan bertanya pada siswa sekolah dasar. Melalui permainan, kegiatan pembelajaran dirancang guru agar siswa dapat mengembangkan keterampilan observasi, melatihkan keterampilan berbahasa, mengembangkan daya ingat, menerapkan pengetahuan yang didapat, serta berlatih mengembangkan ide-ide baru. Kegiatan permainan What's In Here? digunakan sebagai langkah awal melatih siswa mengajukan pertanyaan, misalnya untuk menebak nama benda yang berada di dalam kotak berdasarkan ciri fisik atau yang lainnya dari benda tersebut. 


\section{DAFTAR PUSTAKA}

Feasey, Rosemary. 2009. Jumpstart! Science. Games and Activities for Ages 5-11. A David Fulton Book. London and New York : Routledge

Nurhayati, Eti. 2011. Psikologi Pendidikan Inovatif. Yogyakarta : Pustaka Belajar

Peacock, Alan. 2000. Science Skills. A Problem Solving Activities Book. London : Routledge.

Permendikbud No. 81A tahun 2013 tentang Implementasi Kurikulum 2013.

Sapa'at, Asep. 2012. Seni Bertanya Efektif di Kelas. http://m.republika.co.id. Diakses pada tanggal 15 Januari 2014.

Yusuf, Syamsu. 2011. Psikologi Perkembangan Anak dan Remaja. Bandung : PT.

Remaja Rosdakarya. 